\title{
Investigation of omeprazole stability in oral suspensions for pediatric use prepared extemporaneously from omeprazole capsules
}

\author{
Jela Milić1*, Branko Radojković², Biljana Jančić-Stojanović ${ }^{3}$, \\ Jasmina Drašković ${ }^{4}$, Slavica Miraševićc ${ }^{4}$, Bojan Čalija ${ }^{1}$
}

${ }^{1}$ University of Belgrade - Faculty of Pharmacy, Department of Pharmaceutical Technology and Cosmetology, Vojvode Stepe 450, 11 221, Belgrade, Serbia

${ }^{2}$ Clinical Pharmacist Manufacturing Services, Royal Prince Alfred Hospital, Missenden Road, Camperdown NSW 2050, Australia

${ }^{3}$ University of Belgrade - Faculty of Pharmacy, Department of Drug Analysis, Vojvode Stepe 450, 11 221, Belgrade, Serbia

${ }^{4}$ Pharmacy „Belgrade” - „1.maj”, Kralja Milana 9, 11000 Belgrade, Serbia

Corresponding author: Jela Milić, E-mail: jela@pharmacy.bg.ac.rs

\begin{abstract}
In this paper, a study exploring the stability of omeprazole in pediatric suspensions is presented. In order to determine the most suitable suspension, three different formulations were prepared and stored under refrigerated conditions and at room temperature for 30 days. Contents of omeprazole and preservatives were determined by liquid chromatographic method. Obtained results demonstrate that the vehicle consisting of: xanthan gum $0.3 \%$, sodium bicarbonate $8 \%$, Compound hydroxybenzoate solution APF $1 \%$ and purified water to $100 \%$ could have a significant potential in the development of a suitable omeprazole oral liquid for pediatric use. Namely, the content of omeprazole in the suspension prepared with this vehicle remained within acceptable range during the 30 -day period, when stored refrigerated $\left(2-8{ }^{\circ} \mathrm{C}\right)$.
\end{abstract}

Key words: omeprazole, stability, pediatric suspension, liquid chromatography 


\section{Introduction}

Omeprazole (Figure 1) is a proton pump inhibitor (PPI) commonly prescribed in pediatric and neonate population. These patients require oral medications to be given in the liquid form and, as can be seen in Table I, there is no such product available commercially. For that reason, omeprazole oral liquid products are commonly prepared extemporaneously. Stability of omeprazole in commercial vehicles, such as SyrSpend SF Alka, has been previously confirmed [1], however, the use of such vehicles is frequently limited by their cost and problematic availability on the market of Republic of Serbia. Zegerid ${ }^{\mathbb{Q}}$ powder for oral suspension is marketed in USA and, although it is intended that the product is reconstituted immediately before use, the omeprazole suspensions prepared in such a way have also demonstrated satisfactory stability [2], but this product is also unavailable on the local market.

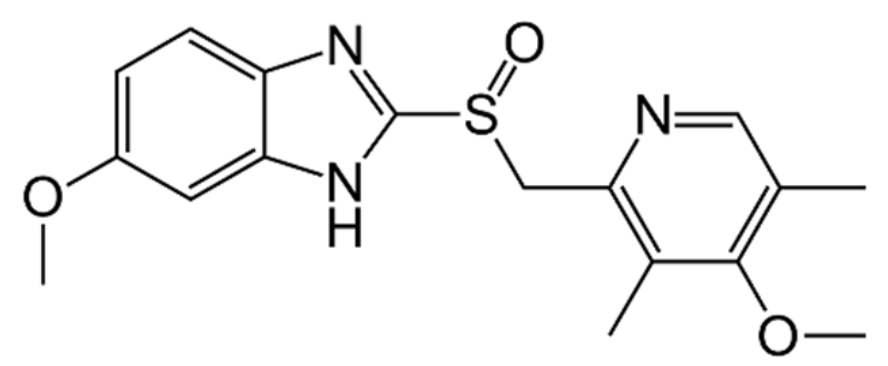

Figure 1. Structure of omeprazole

Slika 1. Struktura omeprazola

Therefore, this study was designed to determine the physical and chemical stability of three omeprazole $2 \mathrm{mg} / \mathrm{mL}$ oral suspension formulations, prepared from commercially available omeprazole capsules, low cost and easily available excipients, and to identify the most suitable candidate for further studies and its possible inclusion in the national formulary. 
Table I Omeprazole drugs for oral administration marketed in Serbia*.

Tabela I Lekovi omeprazola za oralnu upotrebu, koji imaju dozvolu/,registrovani” u Srbiji

\begin{tabular}{|c|c|c|c|c|}
\hline Trade name & Manufacturer & $\begin{array}{l}\text { Omperazole } \\
\text { content per } \\
\text { single dosage } \\
\text { form, mg }\end{array}$ & Dosage form & Packaging \\
\hline Loseprazol $^{\circledR}$ & $\begin{array}{l}\text { PRO. MED. CS } \\
\text { PRAHA A.S. }\end{array}$ & 20 & $\begin{array}{l}\text { gastro-resistant } \\
\text { capsules, hard }\end{array}$ & blister, 2 x 7 pcs. \\
\hline Omeprazid $^{\circledR}$ & $\begin{array}{l}\text { NOBEL ILAC } \\
\text { SANAYII VE } \\
\text { TICARET A.S. }\end{array}$ & 20 & $\begin{array}{l}\text { gastro-resistant } \\
\text { capsules, hard }\end{array}$ & blister, $2 \times 7$ pcs. \\
\hline Omeprazol & REMEDICA LTD & 20 & $\begin{array}{l}\text { gastro-resistant } \\
\text { capsules, hard }\end{array}$ & blister, 2 x 7 pcs. \\
\hline Omeprazol & $\begin{array}{c}\text { HEMOFARM AD } \\
\text { VRŠAC }\end{array}$ & 20 & $\begin{array}{l}\text { gastro-resistant } \\
\text { capsules, hard }\end{array}$ & blister, 2 x 7 pcs. \\
\hline Omeprazol & $\begin{array}{c}\text { HEMOFARM AD } \\
\text { VRŠAC }\end{array}$ & 20 & $\begin{array}{l}\text { gastro-resistant } \\
\text { capsules, hard }\end{array}$ & $\begin{array}{c}\text { plastic } \\
\left(\mathrm{HDPE}^{* *}\right) \\
\text { bottle, } 1 \text { x } 15 \\
\text { pcs. } \\
\end{array}$ \\
\hline Omeprol $^{\circledR}$ & $\begin{array}{l}\text { ZDRAVLJE AD } \\
\text { LESKOVAC }\end{array}$ & 20 & $\begin{array}{l}\text { gastro-resistant } \\
\text { capsules, hard }\end{array}$ & blister, 3 x 5 pcs. \\
\hline Ortalox $^{\circledR}$ & $\begin{array}{c}\text { JADRAN } \\
\text { GALENSKI } \\
\text { LABORATORIJ } \\
\text { D.D. } \\
\end{array}$ & 10 & $\begin{array}{l}\text { gastro-resistant } \\
\text { capsules, hard }\end{array}$ & $\begin{array}{c}\text { plastic (HDPE) } \\
\text { bottle, } 1 \text { x } 28 \\
\text { pcs. }\end{array}$ \\
\hline Ortalox $^{\circledR}$ & $\begin{array}{c}\text { JADRAN } \\
\text { GALENSKI } \\
\text { LABORATORIJ } \\
\text { D.D. }\end{array}$ & 20 & $\begin{array}{l}\text { gastro-resistant } \\
\text { capsules, hard }\end{array}$ & $\begin{array}{c}\text { plastic (HDPE) } \\
\text { bottle, } 1 \text { x } 28 \\
\text { pcs. }\end{array}$ \\
\hline Ortalox $^{\circledR}$ & $\begin{array}{c}\text { JADRAN } \\
\text { GALENSKI } \\
\text { LABORATORIJ } \\
\text { D.D. }\end{array}$ & 20 & $\begin{array}{l}\text { gastro-resistant } \\
\text { capsules, hard }\end{array}$ & $\begin{array}{c}\text { plastic (HDPE) } \\
\text { bottle, } 1 \text { x } 14 \\
\text { pcs. }\end{array}$ \\
\hline
\end{tabular}

* The only omeprazol drug for non-oral administration marketed in Serbia is Omeprol $^{\circledR}$, powder for solution for infusion

** high density polyethylene 


\section{Experimental}

\section{Reagents}

All the reagents utilized in this study were of the analytical grade. The mobile phase and the solvents were prepared from acetonitrile (Avantor Performance Materials $B V$, Deventer, Netherlands), potassium hydrogen phosphate (Riedel-de Haën, SigmaAldrich Laborchemikalien GmbH, Seelze, Germany), sodium hydroxide (Riedel-de Haën, Sigma-Aldrich Laborchemikalien GmbH, Seelze, Germany) and HPLC grade water.

The analyzed substances omeprazole, methyl $p$-hydroxybenzoate (MP) and propyl $p$-hydroxybenzoate (PP) were of analytical grade.

\section{Standard solutions}

Standard solutions of omeprazole for calibration curve were prepared in mobile phase. Five solutions in concentration range from $0.025 \mathrm{mg} \mathrm{mL}^{-1}$ to $0.150 \mathrm{mg} \mathrm{mL}^{-1}$ were prepared.

Standard solutions of MP and PP for calibration curves were prepared in mobile phase. Five solutions in concentration range from $0.0125 \mathrm{mg} \mathrm{mL}^{-1}$ to $0.0750 \mathrm{mg} \mathrm{mL}^{-1}$ and from $0.0625 \mathrm{mg} \mathrm{mL}^{-1}$ to $0.375 \mathrm{mg} \mathrm{mL}^{-1}$ were prepared for MP and PP, respectively.

\section{Suspension samples preparation}

All the formulations were prepared in concentration of $2 \mathrm{mg} \mathrm{mL}^{-1}$ omeprazole content, which is most commonly prescribed. The samples were prepared with the commercially available omeprazole capsules as a source of active ingredient. The compositions of investigated formulations are listed in Table II. 
Table II Composition of investigated samples

Tabela II Sastav ispitivanih formulacija

\begin{tabular}{|l|c|c|c|}
\hline \multirow{2}{*}{ Composition } & \multicolumn{3}{|c|}{ Sample label } \\
\cline { 2 - 4 } & F1 & F2 & F3 \\
\hline $\begin{array}{l}\text { Omeprazole capsules } \\
\text { equivalent to 200 mg } \\
\text { omeprazole }\end{array}$ & $200 \mathrm{mg}$ & $200 \mathrm{mg}$ & $200 \mathrm{mg}$ \\
\hline Glycerol 85\% & $15 \mathrm{~g}$ & - & - \\
\hline Carmellose sodium 5\% gel & $15 \mathrm{~g}$ & - & - \\
\hline Simple syrup & $35 \mathrm{~g}$ & - & - \\
\hline Methyl p-hydroxybenzoate & $100 \mathrm{mg}$ & - & - \\
\hline Propyl p-hydroxybenzoate & $50 \mathrm{mg}$ & - & $8 \mathrm{~g}$ \\
\hline Sodium bicarbonate & - & $8 \mathrm{~g}$ & $1 \mathrm{~mL}$ \\
\hline $\begin{array}{l}\text { Compound } \\
\text { hydroxybenzoate solution } \\
\text { APF* }\end{array}$ & - & $1 \mathrm{~mL}$ & $300 \mathrm{mg}$ \\
\hline Xanthan gum (USP-NF) & - & q. s. $100 \mathrm{~mL}$ & q. s. $100 \mathrm{~mL}$ \\
\hline Purified water & s. $100 \mathrm{~mL}$ & & \\
\hline
\end{tabular}

* Methyl hydroxybenzoate $8 \%$ and Propyl hydroxybenzoate 2\% in Propylene glycol

F1 formulation is frequently prepared in local pharmacies. The contents of omeprazole capsules (enteric-coated pellets) were pulverized, with $\left(\mathrm{F} 1^{*}\right)$ and without pre-treatment with ethanol (F1). Some centers report pre-treatment of omeprazole pellets with $5 \mathrm{~mL}$ of Ethanol $96 \%$ as a processing aid [3].

Formulation F2 presents Australian pharmaceutical formulary and handbook $22^{\text {nd }}$ edition (APF22) officinal Omeprazole dispersion [4].

Formulation F3 is a modification of the APF22 formula: Xanthan gum USP-NF $0.3 \%$ was added as a rheology modifier, in order to improve the physical properties of the suspension. The choice of excipients in this formulation was based on previously reported chemically stable suspension formulation, with proven record of efficacy (simple omeprazole dispersion in sodium bicarbonate solution, as recorded in APF22), while attempting to improve its physical properties by increasing viscosity and thus resuspendability and dosing accuracy. The choice of Xanthan gum as a thickener was 
based on its long history of safe use in oral medications, as well as the stability study of the reconstituted Zegerid ${ }^{\circledR}$ powder, which contains this excipient. A conscious effort was made to develop simple and affordable formulation, allowing for straightforward preparation from readily available ingredients.

The following procedure is recommended for preparation of this suspension:

1. Place in a suitable vessel approximately $85 \%$ of the final volume $(85 \mathrm{ml}$ for each $100 \mathrm{ml}$ of suspension) of freshly boiled and cooled purified water. Place this on a magnetic stirrer and mix on sufficiently high speed to form a stable vortex.

2. Sift the xanthan gum into the vortex and continue mixing on a high speed, in a covered vessel, until gum is completely hydrated. The resulting mucilage is opalescent and free from undispersed agglomerates.

3. Add compound hydroxybenzoate solution to the mucilage and continue mixing until homogenous.

4. Add sodium bicarbonate and continue mixing until completely dissolved.

5. Empty the contents of omeprazole capsules into a porcelain mortar. Carefully pulverise the granules, avoiding any losses.

6. Levigate the resulting powder with small portion of the mucilage. Mix in approximately half of the remaining mucilage, in portions, mixing well after each addition. Transfer this into the measuring cylinder.

7. Rinse the mortar with remaining mucilage, in portions, and add these to the measure.

8. Rinse the mucilage vessel and the mortar with few small aliquots of purified water. Add these to the measure.

9. Make up to final volume with purified water. Mix until homogenous, bottle and label as required.

\section{The investigation of stability}

Stability of the samples was studied in regards to storage temperature (refrigerated and room temperature), packaging (amber glass), and pre-treatment of omeprazole pellets (pellets pulverized with and without pre-treatment with ethanol). The samples have been evaluated visually for homogeneity and appearance, the $\mathrm{pH}$ values measured (potentiometric method), and the contents of omeprazole determined, immediately after preparation and over the 30-day period utilizing liquid chromatographic method. 


\section{Chromatographic conditions}

The chromatographic system Waters Breeze (USA) consisted of Waters 1525 Binary HPLC Pump, Waters 2487 UV/VIS dual absorbance detector and Breeze Software Windows XP for data collection. Separations were performed on the Zorbax Eclipse XDB-C18 $4.6 \mathrm{~mm} \times 150 \mathrm{~mm}, 5 \mu \mathrm{m}$ particle size column (Agilent Technologies, USA). UV detection was performed at $280 \mathrm{~nm}$. The samples were introduced through a Rheodyne injector (USA) valve with a $20 \mu \mathrm{L}$ sample loop. Mobile phase consisted of $32 \%$ acetonitrile and $68 \%$ aqueous solution. Aqueous solution contains $50 \mathrm{mM}$ potassium hydrogen phosphate and $\mathrm{pH}$ value of this solution was adjusted to 7.0 with $1 \mathrm{M}$ solution of sodium hydroxide. Flow rate was $1 \mathrm{~mL} \mathrm{~min}^{-1}$ and column temperature was $25^{\circ} \mathrm{C}$. UV detection was carried out at $280 \mathrm{~nm}$.

\section{Results and discussion}

In the beginning of the study, some important characteristics of omeprazole were realized. Omeprazole has two pKa values (4.0 and 8.7 originate from pyridinium and benzimidazole, respectively). In respect to solubility, it is very slightly soluble in water, soluble in methylene chloride, sparingly soluble in ethanol and in methanol [5]. It dissolves in dilute solutions of alkali hydroxide.

PPIs are the most effective medications used in treatment of gastroesophageal reflux disease (GERD). Omeprazole is commonly prescribed to infants and children with GERD, and alongside its enantiomer esomeprazole, is the only PPI approved for use in pediatrics in Europe [6]. As it was shown in Table I, on the market of Republic of Serbia, omeprazole for oral use is available solely in the form of hard gelatin capsules filled with gastro-resistant pellets, in $10 \mathrm{mg}$ and $20 \mathrm{mg}$ doses [7]. The capsules are intended to be swallowed whole, although in practice it has been reported that the capsules may be opened and the contents mixed with suitable liquid or soft non-alkaline food (e.g., fruit juice, apple puree and fruit yoghurt) immediately before administration. Caution must be taken that the pellets are not crushed or chewed on, in order to preserve their enteric coating. This administration method may be suitable for people with swallowing difficulties and children, but it is not adequate for administration via feeding tubes (pellets tend to block the tubes) and toddlers (chewing on pellets, fraction of dose required). For use in this group of patients, omeprazole has to be extemporaneously prepared in the form of oral suspension. Bioavailability of such suspensions is lower in comparison to enteric-coated products, due to rapid degradation of omeprazole in acidic $\mathrm{pH}$ (stomach). In order to improve bioavailability, and reduce the degradation of omeprazole, oral suspensions are commonly prepared with the addition of an antacid (sodium bicarbonate or calcium carbonate), where the temporary rise in $\mathrm{pH}$ of stomach content is thought to protect the omeprazole from degradation [8,9]. This approach is utilized in commercially marketed Zegerid ${ }^{\circledR}$ OTC capsules and Zegerid ${ }^{\circledR}$ powder for 
oral suspension; neither of which is enteric coated, but rather they both contain sodium bicarbonate. Packets of powder for oral suspension contain either $40 \mathrm{mg}$ or $20 \mathrm{mg}$ of omeprazole, $1680 \mathrm{mg}$ of sodium bicarbonate, and the following excipients: xylitol, sucrose, sucralose, xanthan gum, and flavorings [10]. Omeprazole is highly unstable in acidic conditions $(\mathrm{pH}<7.8)[11]$ and as such it is not compatible with acidic excipients commonly used in preparation of oral liquids (for example Vehicle for oral suspension USP40-NF35 and Vehicle for oral solution USP40-NF35, which are buffered to $\mathrm{pH} 4.0$ 5.0) [12]. Under these conditions, omeprazole is only very slightly soluble and most of it will be suspended in the vehicle, necessitating the addition of suitable suspending agents or rheology modifiers/thickeners, in order to allow precise dosing. These products are commonly preserved with parabens, which are antimicrobially active at $\mathrm{pH}$ 8 , although non-preserved formulations have been reported.

In order to determine content of omeprazole in the formulations liquid chromatographic (LC) method was used. Literature survey shown that LC method presents the most often used method for its determination in different samples [13-15]. In this study, aim of chromatographic analysis was adequate separation between omeprazole and preservatives (MP and PP). Desired characteristics of chromatographic analysis were achieved under chromatographic conditions described in Experimental part. Obtained results for calibration curves are presented in Table III.

Table III Parameters of calibration curves for omeprazole, methyl $p$-hydroxybenzoate and propyl p-hydroxybenzoate

Tabela III Parametri kalibracionih krivih za omeprazol, metil-p-hidroksibenzoat i propil-phidroksibenzoat

\begin{tabular}{|l|c|c|c|c|}
\hline Substance & $\begin{array}{c}\text { Coefficient of } \\
\text { correlation }\end{array}$ & $\begin{array}{c}\text { Intercept } \\
\text { (b) }\end{array}$ & $\begin{array}{c}\text { p-value for the } \\
\text { intercept }\end{array}$ & $\begin{array}{c}\text { Slope } \\
\text { (a) }\end{array}$ \\
\hline Omeprazole & 0.9994 & 68.35391 & 0.224 & 30.415 \\
\hline MP* & 0.9992 & -124.195 & 0.0243 & 35.770 \\
\hline PP** & 0.9985 & -22.1995 & 0.290 & 31.128 \\
\hline
\end{tabular}

MP* - Methyl $p$-hydroxybenzoate

PP** - Propyl $p$-hydroxybenzoate

On the basis of calibration curves contents of omeprazole, MP and PP were determined in investigated formulations. Contents of omeprazole are presented in Table 
IV, while concentrations of MP and PP were in range from $90 \%$ from $110 \%$ in all investigated points.

Table IV Results for Omeprazole determination in different formulations (stored in amber glass bottles, refrigerated at $2-8{ }^{\circ} \mathrm{C}$ or kept at room temperature)

Tabela IV Rezultati određivanja sadržaja omeprazola u ispitivanim formulacijama (čuvanim u tamnim staklenim bočicama u frižideru na temperaturi $2-8{ }^{\circ} \mathrm{C}$ ili sobnoj temperaturi)

\begin{tabular}{|l|c|c|c|c|c|}
\hline \multirow{2}{*}{ Formulation } & \multirow{2}{*}{$\begin{array}{c}\text { Tempera } \\
\text { ture }\end{array}$} & \multirow{2}{*}{$\begin{array}{c}\text { pH } \\
\text { value }\end{array}$} & \multicolumn{3}{|c|}{ Content of omeprazole (\%) } \\
\cline { 5 - 6 } & & & after $24 \mathrm{~h}$ & after 7 days & after 30 days \\
\hline F1 & $2-8^{\circ} \mathrm{C}$ & 7.72 & 88.3 & 84.9 & 81.0 \\
\hline F1 & $20-25^{\circ} \mathrm{C}$ & 7.72 & 83.5 & 72.3 & 61 \\
\hline F1* & $2-8^{\circ} \mathrm{C}$ & 7.52 & 82.8 & 77.1 & 73.0 \\
\hline F1* & $20-25^{\circ} \mathrm{C}$ & 7.52 & 77.6 & 68 & 35 \\
\hline F2 & $2-8^{\circ} \mathrm{C}$ & 8.59 & 98.5 & 93.3 & 100.0 \\
\hline F3 & $2-8^{\circ} \mathrm{C}$ & 8.05 & 95.1 & 97.4 & 101.3 \\
\hline
\end{tabular}

*content of omeprazole capsules pretreated with ethanol

Since GERD is a chronic disorder that usually requires long term therapy, the product with a demonstrated stability of at least one month was considered suitable since, medications for chronic disorders are usually dispensed in monthly intervals. A 30-days long stability study was performed as an initial assessment of feasibility of the extemporaneous preparation of such a product, with the requirement that product retains minimum $95 \%$ of the declared concentration of omeprazole, when kept under defined storage conditions.

Obtained results (Table IV) favor mechanical pulverization of pellets or their dispersion in an alkaline medium (pulverization of pellets pretreated with ethanol has resulted in suspensions with significantly reduced omeprazole contents), as well as refrigerated storage. Samples F2 and F3 retained more than 95\% of initial omeprazole contents when stored refrigerated $\left(2-8{ }^{\circ} \mathrm{C}\right)$ over the 30 -day period. These findings correspond with the literature data regarding chemical stability of simple omeprazole dispersions with sodium bicarbonate $[2,16]$. APF22 officinal Omeprazole dispersion (sample F2) was proven to be difficult to prepare since the pellets took many hours (overnight) to fully disintegrate in the sodium bicarbonate solution. Also, due to the absence of any rheology modifiers, this product shows high rate of sedimentation and the sediment is prone to caking, both of these factors likely affecting the precision of dosing. Sample F3, which contained pulverized omeprazole pellets in a vehicle 
containing xanthan gum, sodium bicarbonate and parabens, has demonstrated better physical properties in comparison to sample F2. Xanthan gum was added into sample F3 as a suspending and stabilizing agent, in order to obtain homogenous suspension that can be easily resuspended.

Storage at controlled room temperature of sample F1 resulted in significant omeprazole losses: only $35-61 \%$ of the declared omeprazole content retained after 30 days. Representative chromatogram of one formulation is presented in Figure 2.

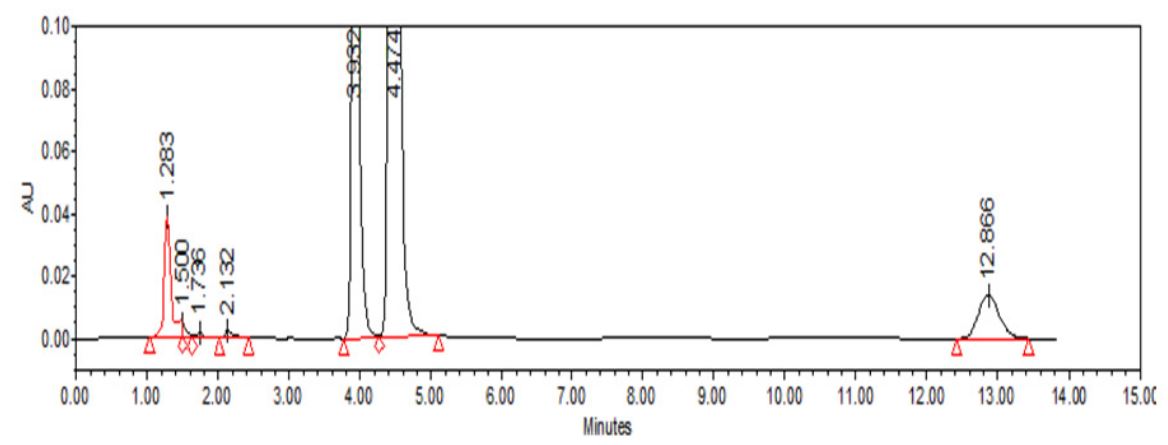

Figure 2. Chromatogram of sample F1: methyl $p$-hydroxybenzoate 3.932 min., omeprazole $4.474 \mathrm{~min}$. and propyl $p$-hydroxybenzoate $12.866 \mathrm{~min}$.

Slika 2. Hromatogram uzorka F1: metil-p-hidroksibenzoat 3,932 min., omeprazol 4,474 min i propil-p-hidroksibenzoat 12,866 min.

\section{Conclusion}

The findings of this study demonstrate that an extemporaneously compounded vehicle consisting of: xanthan gum $0.3 \%$, sodium bicarbonate $8 \%$, Compound hydroxybenzoate solution APF $1 \%$ and purified water to $100 \%$ is an adequate suspending vehicle for preparing individually compounded omeprazole oral liquid formulations. This formulation can be considered stable for 30 days when stored in an amber glass bottle, refrigerated at $2-8{ }^{\circ} \mathrm{C}$ and therefore, has significant potential as viable alternative to commercially available capsules when that dosage form is found to be inappropriate.

\section{Literature}

1. Whaley PA, Voudrie $2^{\text {nd }}$ MA, Sorenson B. Stability of Omeprazole in SyrSpend SF Alka, Int J Pharm Compd. 2012 Dec;16(2): 164-6.

2. Burnett JE,Balkin ER, Burnett JE,Balkin ER. Stability and viscosity of a flavored Omeprazole oral suspension for pediatric use. Am J Health Syst Pharm. 2006 Nov;63(22):2240-7. 
3. Compounding Today [cited 2007 Feb 21]. Available from: https://compoundingtoday.com/Login.cfm?DEST=/Formulation/FormulaPDF.cfm\&QS=FormulaI $\mathrm{D}=1139 \& \mathrm{~S}$ tat $=-2$.

4. Sansom LN, ed. APF 22, Pharmaceutical Society of Australia, Canberra, 2012. p. 515.

5. The European Pharmacopoeia 9th Edition, Strasbourg: Council of Europe, 2017. p. 3211.

6. Vandenplas Y, Rudolph CD, Di Lorenzo C, Hassall E, Liptak G, Mazur L, Sondheimer J, Staiano A, Thomson M, Veereman-Wauters G, Wenzl TG. Pediatric gastroesophageal reflux clinical practice guidelines: joint recommendations of the North American Society for Pediatric Gastroenterology, Hepatology, and Nutrition (NASPGHAN) and the European Society for Pediatric Gastroenterology, Hepatology, and Nutrition (ESPGHAN). J Pediatr Gastr Nutr. 2009 Oct 1;49(4):498-547.

7. Medicines and Medical Devices Agency of Serbia [cited 2017 Feb 20]. Available from: http://www.alims.gov.rs/eng/medicinal-products/search-for-human-medicines/

8. Sharma VK, Peyton B, Spears T, Raufman JP, Howden CW. Oral pharmacokinetics of omeprazole and lansoprazole after single and repeated doses as intact capsules or as suspensions in sodium bicarbonate. Aliment Pharm Ther. 2000 Jul 1;14(7):887-92.

9. Johnson CE, Cober MP, Ludwig JL. Stability of partial doses of omeprazole-sodium bicarbonate oral suspension. Ann Pharmacother. 2007 Dec 1;41(12):1954-61.

10. Zegerid product information [cited 2007 Mar 15]. Available from: http://www.accessdata.fda.gov/drugsatfda_docs/label/2014/021849s010021636s0161bl.pdf.

11. Mathew M, Gupta VD, Bailey RE. Stability of omeprazole solutions at various $\mathrm{pH}$ values as determined by high-performance liquid chromatography. Drug Dev Ind Pharm. 1995 Jan 1;21(8):965-71.

12. The United States Pharmacopeia - National Formulary (USP 40-NF 35), Rockville: United States Pharmacopeial Convention, Inc., 2016: 7788-7789.

13. Patel MM, Bhuva SD, Patel HD, Mori KN. An overview of the recent developments in analytical methodologies for determination of proton pump inhibitors in bulk drugs, pharmaceuticals and biological matrices, Eurasian J Anal Chem. 2014 Mar; 9(1), 49-57.

14. Houshe S, Bachour G, Chehna MF. Development of rapid and simple analytical method for some proton pump inhibitors (PPI-s) using HPLC, Jordan J. Pharm. Sci. 2011 Jan; 4(3); 222-36.

15. Kulkarni AS, Balkrishna MV. Method development and validation for the simultaneous determination of omeprazole and domperidone in solid dosage form by RP-HPLC, Int. J. Pharm. Pharm. Sci. 2012; 4(5): 109-14.

16. Quercia RA, Fan C, Liu X, Chow MS. Stability of omeprazole in an extemporaneously prepared oral liquid. Am J Health Syst Pharm. 1997 Aug; 54(16): 1833-6. 


\title{
Ispitivanje stabilnosti oralnih suspenzija omeprazola za pedijatrijsku primenu magistralno izrađenih iz omeprazol kapsula
}

\author{
Jela Milić ${ }^{1 *}$, Branko Radojković ${ }^{2}$ Biljana Jančić-Stojanović ${ }^{3}$ \\ Jasmina Drašković́ ${ }^{4}$, Slavica Mirašević ${ }^{4}$, Bojan Čalija ${ }^{1}$ \\ ${ }^{1}$ Univerzitet u Beogradu - Farmaceutski fakultet, Katedra za farmaceutsku tehnologiju i \\ kozmetologiju, Vojvode Stepe 450, 11 221, Beograd, Srbija \\ ${ }^{2}$ Odsek za farmaciju, Royal Prince Alfred Hospital, Sidnej, Missenden Road, \\ Camperdown NSW 2050, Australija \\ ${ }^{3}$ Univerzitet u Beogradu - Farmaceutski fakultet, Katedra za analitiku lekova, Vojvode \\ Stepe 450, 11 221, Beograd, Srbija \\ ${ }^{4}$ Apoteka „Beograd” - „1.maj”, Kralja Milana 9, 11000 Beograd, Srbija
}

Autor za korespondenciju: Jela Milić,E-mail: jela@pharmacy.bg.ac.rs

\section{Kratak sadržaj}

U ovom radu predstavljeno je ispitivanje stabilnosti omeprazola u suspenzijama za pedijatrijsku primenu, koje su izrađene iz komercijalno dostupnih kapsula omeprazola $\mathrm{u}$ uslovima apoteke. U cilju utvrđivanja najpogodnijeg vehikuluma za magistralnu izradu suspenzija omeprazola, pripremljene su tri formulacije, koje su potom 30 dana čuvane u frižideru i na sobnoj temperaturi. Sadržaj omeprazola i konzervansa u suspenzijama je određivan primenom tečne hromatografije. Dobijeni rezultati ukazuju da vehikulum koji se sastoji iz ksantan gume $0,3 \%$, natrijum-bikarbonata $8 \%$, rastvora parabena $1 \%$ (Compound hydroxybenzoate solution $A P F)$ i prečišćene vode do $100 \%$ ima značajan potencijal za razvoj pogodnog tečnog oblika omeprazola za peroralnu primenu u pedijatrijskoj populaciji. Naime, sadržaj omeprazola u suspenziji pripremljenoj primenom ovog vehikuluma je ostao u okviru prihvatljivih granica tokom perioda od 30 dana, kada je suspenzija čuvana u frižideru $\left(2-8^{\circ} \mathrm{C}\right)$.

Ključne reči: omeprazol, stabilnost, suspenzija za pedijatrijsku primenu, tečna hromatografija 